tion of Minikoi, of which a map is given. Although at one point the land is gaining on the lagoon, in others it is gradually diminishing, and the author prophesies that in course of time the sea will make a clean sweep of some parts of the atoll.

Much attention is devoted to the mode of formation of a coral conglomerate found in Minikoi and elsewhere at the base of the outer beach. From the presence of this conglomerate and other evidence, the author concludes that an elevation of at least 24 feet must be admitted to have taken place in Minikoi, and this during the time that it has existed as an atoll. "The presence of conglomerate masses," he adds, "I can only regard as indicating the existence of former land in any position where they now occur. The land there must have at one time extended round the whole island with only a single break, perhaps to the north, with lower parts here and there, where boat-channels across the reef now exist." Minikoi was indeed once apparently very like some of the low coral-islands of the Maldive group in the Indian Ocean and the Ellice group in the Pacific. For the final chapters on Minikoi we must await another fasciculus of the work.

The groups of the Minikoi fauna included in this fasciculus comprise the Hymenoptera, by Mr. P. Cameron; the land crustaceans, by Mr. L. A. Borradaile; and the nemertean worms, by Mr. R. C. Punnett. Among the second of these perhaps the most generally interesting group are the land hermit-crabs of the genus Coenobita. Like the great cocoanut crab (Birgus latro), these crabs have forsaken the sea for a life on land, although (unlike the former) they still retain the habit of sheltering the abdomen within a shell or some such covering. In the case of a specimen of which the figure is here reproduced, the abdomen is encased in the broken shell of a cocoanut. Among the nemertean worms, a genus hitherto known only from Amboina has been met with again at Minikoi.

R. L.

\section{PROF. MAXWELL SIMPSON, F.R.S.}

M AXWELL SIMPSON, ninth and youngest child of I the late Thomas Simpson, was born at Beech Hill, co. Armagh, Ireland, on March 15, 1815. Educated at a private school in Newry, he thence proceeded to Trinity College, Dublin, where he took his Arts degree, and subsequently entered the School of Medicine. In r 847 he graduated as Bachelor of Medicine in Trinity College ; but already he had been strongly attracted towards the study of chemistry, and instead of settling down to the practice of physic, he now became associated, as lecturer in chemistry, with the medical school of Park Street, Dublin. This school had been established about 1824 by a number of physicians and surgeons, and had included among its teachers James Apjohn, subsequently professor of chemistry in the University of Dublin. From Park Street he was transferred to the Peter Street School of Medicine, where he remained for a few years.

Inspired, however, by a profound love for science, the limitations incidental to such a post grew irksome to him ; the desire to secure adequate outlet for his intellectual energies, to prosecute his own inquiries, and to enjoy the communion of fellow-workers intensified with time, until finally, casting aside all material considerations, he relinquished his teaching and proceeded to the Continent, where, associated with some of the most eminent chemists of the day, he was free to breathe the congenial atmosphere of research.

Plunging with characteristic energy and enthusiasm into work, he soon became productive. In $185 \mathrm{I}$ he studied with Kolbe at Marburg, then under Bunsen at Heidelverg, conducting in the laboratory of the latter an investi- gation on which his first original paper was based; this communication, "On two new Methods for the Determination of Nitrogen in Organic and Inorganic Compounds," published in the Journal of the Chemical Society (vi. 289) and in the Annalen der Chemie und Pharmacie (xcv. 63), foreshadowed the accuracy and thoroughness which were to mark his later work.

Moving next to Paris, and entering the laboratory of Wurtz, his attention naturally became centred on organic chemistry, and here his capacity for work was quickly manifested ; commencing with a paper on the "Action du Brome sur l'Iodure d'Aldéhydène," read before the Académie des Sciences on March I, I858, one memoir followed another in rapid succession. In April he made a communication "Sur une Base nouvelle obtenue par l'action de l'Ammoniaque sur le Tribromure d'Allyle," another on the same subject in August, and a third in November on the "Action du Chlorure d'Acétyle sur l'Aldéhyde"; these he followed up by two papers (Proc. Roy. Soc., ix. 725 and x. 1 14) "On the Action of Acids on Glycol." On April 25, 1861, Prof. Frankland communicated, on his behalf, to the Royal Society the first of two important papers "On the Synthesis of Succinic and Pyrotartaric Acids," in which he showed that the former, built up from ethylene, through the dibromide and corresponding cyanide, is identical with common succinic acid ; the latter, from propylene bromide, with the pyrotartaric acid got by distilling natural tartaric acid-thereby establishing the chemical constitution of both. This excellent piece of work met with due recognition, and in I862 Maxwell Simpson was admitted a Fellow of the Royal Society.

Two other communications appeared (Proc. Roy. Soc., xi. 590 and xii. 278) "On the Action of Chloride of Iodine on Iodide of Ethylene and Propylene Gas," and, almost concurrently with these, two more, now classical, "On the Synthesis of Tribasic Acids" (ibid. xii. 236, and Journ. Chem. Soc., 2, iii. 33r); here it was shown that from allyl tribromide, a corresponding tricyanide can be obtained, which by saponification yields a salt of tricarb. allylic acid-this substance is an immediate derivative of glycerine, and "bears the same relation to citric acid that succinic bears to malic acid."

It is not possible within these limits of space adequately to notice Simpson's work or its bearing. Of his further papers may be mentioned : "On the Acids that may be derived from the Cyanides of the Oxy-radicals of the Diand Tri-atomic Alcohols"; "On the direct Transformation of Iodide of Allyle into Iodide of Propyle" ; On the Action of Chloride of Iodine upon Organic Substances"; "On the Formation of Di-iodacetone"; "On the Formation of Succinic Acid from the Chloride of Ethylidene"; " On a new Compound formed by the direct union of Aldehyde and Anhydrous Prussic Acid" (with Dr. Gautier); "On the direct Transformation of Chlor-iodide of Ethylene into Glycol"; "On some new Derivatives of Acetone"; "On the Brom-iodides"; "On the Determination of Urea by means of Hypobromite of Soda" (with Mr. C. O'Keeffe), and a paper (Proc. Roy. Soc., xxvii. I 20) "On compounds of Silver Iodide with Alkyl Iodides." Of the above work, that described in the paper on aldehydes and hydrocyanic acid is especially important, leading, as it did, to the synthetical production of one of the forms of lactic acid.

In 1872, Maxwell Simpson was appointed to the chair of chemistry in Queen's College, Cork, an office which he resigned after nineteen years of service.

His power was by no means confined to the research laboratory; as a lecturer he possessed in a high degree that gift of luminous exposition which is the product of quick and accurate memory, clear intelligence and ready command of language. Simple and unaffected, genial of manner, though strong in the courage of his convictions; direct and original in thought and speech, Simpson's 
personality was forceful, interesting and lovable. Endowed as he was, it may seem strange that he did not establish a school of chemistry in Cork. But the reason is not to be found in the man-rather in his surroundings. Placed, as he was, in a sparsely populated district, where poverty is, unhappily, the rule, where chemical manufactures are but few, and where the demand for highly trained chemical knowledge of any sort is practically non-existent, the result flowed almost inevitably from the conditions.

At various times he acted as examiner in chemistry to the Civil Service of India, the Civil Engineering College, Coopers Hill, and the Royal Military Academy, Woolwich; he was an Honorary Fellow of the King's and Queen's College of Physicians ; received the degrees of M.D. and LL.D. (both honoris causa) from the University of Dublin; was a senator of the Queen's University; Fellow of, and examiner in, the Royal University of Ireland, from which he received the degree of D.Sc. (honoris causa); he was also selected as president of the section of chemistry of the British Association at its meeting in Dublin in 1878 . In addition, he was for several years a member of the council of the Chemical Society, by which he was elected, during the years $1872-$ 74 , to the office of vice-president.

On February 26, Maxwell Simpson passed away in London; his work remains, a worthy and enduring memorial to his love for that science which he so generously enriched.

A. E. DIXON.

NOTES.

Prof. E. C. Pickering announces that he has received from a friend a gift of twenty thousand dollars $(4000 l$.) for the benefit of the Ifarvard College Observatory. . It is proposed to expend about one-half of this fund in extending the present building in which the astronomical photographs are kept, so as to provide for the adequate storing of this collection with its probable increase for many years. These photographs furnish a history of the entire stellar universe for the last twelve years, and is not duplicated elsewhere. A portion of the remainder of the gift will be used at once to provide for the study of objects of interest on the photographs, as hitherto only those of special importance have been examined.

The Raoult Memorial Lecture of the Chemical Society was delivered by Prof. van 't Hoff on Wednesday of last week. Shortly after Raoult's death, a year ago, a short account of his career was given in these columns (vol. lxiv. p. 17). Prof. van't Hoff remarked that the scientific work could be conveniently considered as belonging to three periods of Raoult's lifephysical, chemical and physiological. As a typical research of the first period he mentioned the study of the heat evolved by chemical reactions in the voltaic cell and that due to the electric current. Later, Raoult directed his attention to subjects of a more purely chemical nature, such as the influence of solar radiation on the inversion of cane sugar, and the absorption of ammonia by saline solutions. His physiological work included studies of the presence of copper and zinc in the animal organism and the influence of carbon anhydride on respiration. But Prof. van 't Hoff pointed out that the researches which made Raoult's name famous as a scientific investigator were those which led to the establishment of a definite connection between the lowering of the freezing points and of the vapour pressures of solvents by the presence of dissclved substances. This led Prof. van 't Hoff to the important generalisation that the osmotic pressure of a dissolved substance bears a definite relationship to the pressure it would exert if it were in a state of vapour-a theory which has been of immense service in elucidating the nature of solutions and has also led to the theory now widely NO. I 692, voL. 65$]$ accepted as to the existence in dilute salt solutions of the ions of the dissolved substance.

WE regret to see the announcement of the death on Good Friday of Mr. G. F. Wilson, F.R.S., whose scientific work included the discovery of the means of obtaining pure glycerine, and numerous papers on horticultural subjects. Mr. Wilson was in his eightieth year.

LORD KeLvin is expected to arrive in New York on April 19. Science states that a reception will be given in his honour on the evening of April 21 by Columbia University, the American Institute of Electrical Engineers, the New York Academy of Sciences and other scientific societies.

ON Tuesday next, April 8, Dr. Allan Macfadyen will deliver the first of a course of three lectures at the Royal Institution on "Biological Inquiry"; on Thursday, April 10, Prof. Dewar will begin a course of three lectures on "The Oxygen Group of Elements." The Friday evening discourse on April II will be delivered by Prof. Dewar on "Problems of the Atmosphere," and on April I 8 by Sir John H. A. Macdonald, his subject being " The Autocar."

THE Berlin correspondent of the Times states, upon the authority of the Lokalanzeiger, that a scheme is under consideration by the German Imperial authorities in accordance with which the chief commercial nations, especially England, France and the United States, will be invited to send representatives to an international congress, the object of which will be to arrive at an agreement forbidding the establishment of any monopoly in wireless telegraphy on the high seas. This step, it is stated, is the direct consequence of the refusal of the Marconi station on the Nantucket lightship to enter into communication with the Deutschland during its homeward journey with Prince Henry of Prussia on board.

We learn from the Times that the University of Chicago has commissioned Mr. Alleyne Ireland to report on the financial, commercial and social conditions of all the European colonies in the Far East, where the circumstances appear both geographically and historically to bear some resemblance to the general situation of the Philippines. Mr. Ireland will visit Burma, Siam, the Federated Malay States, the Straits Settlements, Sumatra, Java, British North Borneo, Sarawak, French Indo-China, Tonking, Formosa and Hongkong. After making an investigation of the general condition of the IndoMalayan people under British, Dutch, French, and native rule, he will then go to the Philippines in order to examine the conditions of those islands from the comparative point of view. It is anticipated that his inquiry will occupy about two years.

At the request of the U.S. Senate, the Secretary of Agriculture has reported upon the condition of the American bison. In his summary he states that this species is on the verge of extermination. Scarcely a handful now remain of the millions which formerly roamed over the plains of the west. Only two small herds of wild buffalo are in existence in the United States-one in the Yellowstone Park, the other in Lost Park, Colo. There are no wild buffalo in Canada, except in the Peace river country, where a few woodland buffalo, believed to be a different species from the American plains buffalo, still exist. A number of buffalo have been domesticated and half-domesticated, there being three important herds in addition to the small herds in zoological parks and in the hands of private individuals. It is suggested that if the Government would acquire possession of a considerable number of full-blooded animals the absolute extermination of the species might be long delayed. 